\title{
ЕКОЛОГО-ЕКОНОМІЧНИЙ ВИМІР БЕЗПЕКИ
}

\author{
Турченко О. Г., Краковська А. С.
}

\section{ВСТУП}

На початку XXI ст. трансформаційні процеси в системі міжнародних відносин призвели до виникнення нового комплексу проблем безпеки - загроз, викликів і ризиків нетрадиційного ряду, що відрізняються від традиційних, військово-стратегічних, загроз параметрами свого впливу на сучасні держави і транскордонним характером. Загрози безпеці ускладнилися, набули нового змісту і глобального масштабу, вони дедалі більше детермінуються структурними примусами транснаціонального характеру.

Відповідно, проблема прийняття будь-яких рішень у сфері безпеки стала багатовимірною, й оптимальне вирішення сукупності завдань, пов'язаних із забезпеченням міжнародної безпеки знаходиться в багатовимірному просторі, де дедалі активніше проявляють себе поряд із традиційними нетрадиційні суб'єкти міжнародного права, процеси, які раніше мали суто національний характер, і загалом певним чином «стирається» межа національних інтересів і загальних, «внутрішніх» проблем і загальносвітових. Як зазначає В. Кулагін, у сучасних умовах варто говорити «...не тільки про «міжнародну безпеку» в її міждержавній іпостасі, а про явище з більш широким набором дійових осіб, яке 3 цієї причини більш коректно було б назвати «світовою безпекою»»» ${ }^{1}$.

Проблема ж побудови інтегрованої концепції всеохоплюючої безпеки як одне з основних висуває питання про співвідношення безпеки людства і конкретної нації, міжнародної спільноти та держави, суспільства і особи. Найчастіше бачення необхідності забезпечення безпеки окремої нації принципово суперечить аналогічному баченню інших націй, окремої держави - аналогічному баченню іншої держави. Цю спірну взаємозалежність, як правило, розглядають як основне джерело проблем безпеки в сучасному світі².

Логічно, що більшість авторів доходить висновку, що при формуванні синтетичної концепції безпеки має бути здійснений принциповий вибір між концепціями, орієнтованими тільки на захист

\footnotetext{
1 Кулагин В. Глобальная или мировая безопасность. Международные процессы. Журнал теории международных отнотений и мировой политики. 2007. Том 5. № 2(14). май-август. URL: www.intertrends.ru.

2 Фатхутдинов В. Щодо системного синтезу безпекових концепцій. Підприємництвво, господарство і право. 2012. № 12. С. 109.
} 
інтересів осіб, нації чи окремих держав, і концепціями цілеспрямованого впливу в інтересах нації, осіб і держави для найбільш повного задоволення їх потреб як цілісного організму. Однак критеріїв такого вибору не пропонується.

Своєю чергою, науково-технічна діяльність людини спричинила трансформацію простих економічних, екологічних систем у більш складні, так звані соціально-еколого-економічні системи, які складаються із трьох тісно взаємопов'язаних підсистем: екологічної, економічної та соціальної. Стійка тенденція до зростання ролі екологічних факторів та економічної складової частини природи проблем безпеки зумовлює необхідність налагодження належного рівня міжнародного співробітництва та вибору стратегії розвитку, за якої досягається гармонія екологічних, соціальних, економічних, політичних взаємовідносин, коли стан кожної з підсистем виступає і як умова, і як наслідок розвитку та функціонування двох інших підсистем³

Глобалізація екологічних проблем, сукупна ентропія, що має тенденцію до збільшення, посилення еколого-економічного взаємозв'язку, що базується на єдності природної та господарської підсистем макроекономічної системи будь-якого ієрархічного рівня, зумовлюють необхідність пошуку нових моделей економіки, які б враховували відтворювальні можливості біосфери, давали змогу звести до спільного знаменника біофізичні та вартісні критерії збереження природного капіталу планети ${ }^{4}, \mathrm{i}$, відповідно, актуальність цієї статті та перспективи подальшого дослідження проблем еколого-економічного виміру безпеки, екологічного підприємництва.

Системному осмисленню принципів, здобутків і тенденцій узазначеній сфері з правової точки зору, правовим питанням прогресивного розвитку людства в рамках забезпечення сталого розвитку країн та виконання концепції сталого розвитку міжнародної спільноти присвячені роботи таких вчених, як Т. Гартлі, О.Г. Білорус, Г.С. Бувайлик, М.В. Буроменський, О.Ф. Висоцький, В.Н. Денисов, О.В. Задорожній, О.Д. Урсул тощо.

Серед досліджень правової природи, проблем забезпечення екологічної безпеки необхідно виділити роботи: B.I. Андрейцева, Г.В. Анісімової, Г.І. Балюк, А.Г. Бобкової, М.М. Бринчука, І.В. Бригадира, Ю.О. Вовка, А.П. Гетьмана, О.В. Гулак, В.А. Єгіазарова, Б.В. Єрофєєва, А.Б. Качинського, О.С. Колбасова, В.В. Костицького, М.В. Краснової,

\footnotetext{
3 Олдак П.Г. Общие начала биосоциальных исследований. Теория взаимосвязи общественного производства и окружающей сферы. Москва : Изд-во НГУ, 1977. С. 5.

4 Гринів Л.С. Екологічна економіка. Львів : Магнолія 2006, 2010. С. 46.
} 
Н.Р. Малишевої, М.І. Малишко, В.Л. Мунтяна, В.В. Носіка, В.К. Попова, Г.П. Серова,Н.І. Титової, М.О. Фролова, Ю.С. Шемшученка, М.В. Шульги та інших.

Але незважаючи на доволі велику кількість теоретичних та практичних розробок у цій сфері, єдиного підходу до розуміння взаємозв'язку та взаємозалежності між безпекою і сталим розвитком не вироблено, відсутні також і чіткі механізми, критерії їх забезпечення, єдині критерії визначення загроз у сфері екологічної безпеки, сталого розвитку, механізму реалізації державами своїх зобов'язань у сфері досягнення цілей сталого розвитку.

Мета дослідження - на підставі аналізу сформованих у доктрині підходів, положень міжнародних актів охарактеризувати особливості еколого-економічного виміру безпеки, обгрунтувати взаємозв'язок і взаємозалежність екологічної безпеки та сталого еколого-економічного розвитку, розробити пропозиції щодо формування мети та принципів екологічного підприємництва.

\section{1. Екологія, економіка, безпека: кореляційний зв'язок}

У сучасних наукових дослідженнях питань безпеки дедалі частіше зустрічається точка зору про міждисциплінарність вчення про безпеку. Так, А.Д. Урсул зазначає: «Проблема безпеки в тому чи іншому вигляді існує, якщо поки не у всіх, то в більшості наукових дисциплін, які вивчають вищі форми еволюції матерії, тобто вона має не тільки реальний міждисциплінарний, але і потенційно загальнонауковий характер» ${ }^{5}$.

Аналогічним чином у науці акцентований сталий розвиток. Представник науки міжнародного права М. Фіцморіс зазначає, що сталий розвиток - це «міждисциплінарна концепція» ${ }^{6}$, а О.В. Задорожній, М.О. Медведєва наголошують, що концепція сталого розвитку є однією 3 центральних концепцій міжнародного права навколишнього середовища, міжнародного економічного права, міжнародного права прав людини, міжнародного морського права, а також національних правових систем ${ }^{7}$.

\footnotetext{
5 Урсул А.Д. Проблемы безопасности и устойчивого развития: эволюционный подход и междисциплинарные перспективы. Вопросы безопасности. 2014. № 5. C. 1-62. URL: http://e-notabene.ru/nb/article_14221.html.

6 Fitzmaurice M.A. The contribution of environmental law to the development of modern environmental law / J. Makarczyk (ed.). Theory of International Law at the threshold of the 21st century: Essays in honour of Krzysztof Skubiszewski. The Hague : Kluwer Law International, 1966. P. 16.

Задорожній О.В., Медведєва М.О. Міжнародне право навколишнього середовища : підручник. Київ, 2010. С. 76.
} 
Традиційні підходи, що використовуються в галузі загальної теорії управління, загальної безпеки життєдіяльності, здебільшого виходять із питань безпеки як попередньо визначеного стану, не враховуючи антропогенні фактори, або ж, навпаки, розглядають взаємодію суб'єктів забезпечення безпеки, не враховуючи дуалізм об'єктивного і суб'єктивного у феномені безпеки. Сталим підходом до розв'язання проблем національної безпеки $є$ визначення оптимального співвідношення (комбінації) та підтримання на достатньому стабільному рівні трьох змінних складників: національні інтереси, загрози і небезпеки щодо їх реалізації, можливості держави.

Але видається, що розгляд безпеки через призму аналізу i.i окремих елементів із наступною екстраполяцією на всю систему є недосить коректним і $є$ прямим наслідком застосування редукціоністського підходу, коли властивості цілого визначаються через властивості елементів ${ }^{8}$.

Такий підхід не є гнучким, він не дає змоги враховувати низку важливих факторів, передусім, транскордонного характеру, оперативного реагування на появу нових загроз. Відсутність війни і військових конфліктів між державами сама по собі ще не гарантує стабільність міжнародного миру і його безпеку, бо його підривають не військові, а інші джерела нестабільності - в економічній, соціальній, гуманітарній та екологічній сферах.

Для сучасних викликів характерна зростаюча складність, що, своєю чергою, зумовлена ускладненням технологічних, фінансових і політичних взаємозв'язків у соціально-економічних системах - вони визначають дедалі важче передбачувані нові комбінації параметрів ризику загроз і масштаби їх наслідків. Крім того, виклики і загрози дедалі більше перетворюються на процес, який сам розвивається, нагадуючи замкнуте коло через невизначеність причин і причинно-наслідкових зв'язків, і неефективного управління ними'.

Тому виникає необхідність переходу до нової парадигми безпеки, застосування методології цивілізаційного, системно-синергетичного підходу у процесі формування концепцій безпеки для врахування всіх

\footnotetext{
8 Ліпкан В. Поняття та зміст націобезпекознавства. Право Украӥни. 2003. № 9. С. 115.

9 Колдунова Е.В. Формирование регионального комплекса безопасности в Восточной Азии в свете новых угроз и нетрадиционных аспектов безопасности : автореф. дис. ... канд. полит. наук : 23.00 .04 «Политические проблемы международных отношений и глобального развития». Москва, 2009. С. 14. URL: http://cheloveknauka.com/formirovanie-regionalnogokompleksa-bezopasnosti-v-vostochnoy-azii-v-svete-novyh-ugroz-i-netraditsionnyh-aspektovbezopas\#ixzz4Ld7JBaQE.
} 
факторів, які можуть справити вплив на безпеку, що дасть, своєю чергою, змогу надати традиційній дослідницькій моделі універсальності та гнучкості.

Синергетика (від грецього «синергена» - співробітництво, сприяння) дає змогу розглядати єдину структуру як відкриту нелінійну динамічну систему. Відповідно, під час вивчення безпеки як поліморфного явища застосування синергетики дасть змогу врахувати коливальний характер загальних процесів, знання ж глобальних закономірностей - правильно зорієнтуватися в історичному аспекті, визначити, на якому моменті розвитку знаходиться система безпеки.

Системно-синергетичний підхід, 3 огляду на те, що в будь-якій системі є системоутворювальний зв'язок, як зазначає доктор наук із державного управління, професор Г. Ситник ${ }^{10}$, «відкриває додаткові інструментальні можливості для раціоналізації системного переходу від з'ясування потреб у безпеці (від людини до міжнародної спільноти включно) до пошуку раціональних варіантів управлінських стратегій, орієнтованих на задоволення вказаних потреб».

Не зупиняючись на аналізі всієї історії становлення та закріплення ідеї сталого розвитку, розглянемо особливості еколого-економічного виміру безпеки та взаємозв'язку і взаємозалежності екологічної безпеки та сталого розвитку у XXI столітті.

Ще на першій Міжнародній конференції з охорони природи (листопад 1913 р., м. Берн) П. Саразен висловив переконання в нагальній потребі запровадження всесвітньої охорони природи за допомогою взаємопов'язаних заходів на національному і міжнародному рівнях ${ }^{11}$, що поступово призвело до формування підходу до міжнародної екологічної безпеки як складової частина всеохоплюючої безпеки. Так, В. Василенко в роботі «Екологічна безпека як елемент всеохоплюючої системи міжнародної безпеки» наголошує, що створення ефективної системи міжнародної безпеки як інструменту збереження довкілля Землі $є$ пріоритетом серед пріоритетів міжнародної безпеки, важливішим навіть від проблеми роззброєння і військово-політичної безпеки ${ }^{12}$.

\footnotetext{
10 Ситник Г. Інституційно-цивілізаційна парадигма дослідження проблем та державноуправлінських аспектів забезпечення національної безпеки. Вісник Національної академї державного управління при Президентові України. 2011. Вип. 2. С. 31. URL: http://nbuv.gov.ua/UJRN/Vnadu_2011_2_6.

11 Conférence Internationale pour de la Natur, Berne, 17-19 November 1913, Recueil des Procés-Verbaux, 25-26.

12 Василенко В. Генеза, зміст і шляхи реалізації концепції міжнародної екологічної безпеки. Екологічна Конституиія Землі. Методологічні засади. Львів : РВВ НЛТУ України, 2011. C. 62.
} 
Проведені автором раніше дослідження питань всеохоплюючої безпеки, сталого розвитку, екологічного підприємництва уможливлюють висновок, що, незважаючи на різноманітність підходів до визначення екологічної безпеки, вона [екологічна безпека], як правило, трактується у взаємозв'язку з елементами сталого розвитку ${ }^{13}$.

Такий висновок можна зробити після аналізу таких положень. У Політичній декларації та Плані виконання рішень Всесвітнього саміту зі сталого розвитку (Йоганнесбург, 2002 р.) зазначається необхідність зміни нестійких моделей виробництва і споживання за допомогою екологізації повного життєвого циклу продукції, збереження і раціонального використання природно-ресурсної бази економічного і соціального розвитку із застосуванням екосистемного підходу.

16 жовтня 2003 р. Генеральна Конференція ЮНЕСКО (Резолюція 32C/COM.III/DR.1) визнала Хартію Землі, що закріпила основоположні принципи справедливого, сталого і мирного глобального суспільства в XXI ст., наголошуючи на взаємозалежності світу, взаємній відповідальності всіх, як один перед одним, так і перед усім живим та майбутніми поколіннями ${ }^{14}$.

У Підсумковому документі Всесвітнього саміту 2005 р. (Резолюція Генеральної Асамблеї ООН A/RES/60/1) наголошується, що «....розвиток, мир і безпека і права людини є взаємопов'язаними, розвиток сам по собі є центральною метою і що сталий розвиток у його економічному, соціальному та екологічному аспектах є одним з основних елементів у діяльності всієї системи Організації Об'єднаних Націй» $(п . п . ~ 9, ~ 10)^{15}$.

У 2011 р., розвиваючи положення Глобального зеленого нового курсу, ЮНЕП (Програма ООН із довкілля) присвятила свою нову доповідь «Назустріч «зеленій економіці»: шлях до сталого розвитку та викоріненню бідності» аргументації на користь інвестування $2 \%$ світового внутрішнього валового продукту в «озеленення» десяти

13 Турченко О.Г. Щодо поняття «сталий розвиток». Актуальні проблеми права: теорія $i$ практика. 2017. № 33. С. 155-168; Турченко О.Г. Устойчивое развитие и безопасность: корреляционная зависимость. Sciences of Europe. 2017. Vol. 2, № 19(19). С. 29-35; Турченко О.Г. Екологічна безпека та сталий розвиток: кореляційна залежність. Право Украӥни. 2018. № 5. C. 116-135.

14 Международная Хартия Земли (Международный Совет инициативы Хартия Земли; Международный Секретариат Хартии Земли. Сан-Хосе (Коста-Рика)). URL: http://www.newlineclub.net/downloads/eci/winter\%20school/materials/earth\%20charter/Mezhdunarodny_sovet_ECI.pdf.

15 Resolution adopted by the General Assembly on 16 September 2005 [without reference to a Main Committee (A/60/L.1)] 60/1. 2005 World Summit Outcome. URL: https://documents-dds-ny. un.org/doc/UNDOC/GEN/N05/487/62/PDF/N0548762.pdf?OpenElement. 
найважливіших секторів економіки з метою істотної зміни характеру розвитку та спрямування потоків державних і приватних інвестицій на ефективне використання ресурсів та зменшення викидів парникових газів ${ }^{16}$.

У Доповіді Генерального секретаря Підготовчої конференції ООН зі сталого розвитку (Друга сесія 7 і 8 березня 2011 р.) у п. 58 передбачається концепція екоефективності - раціонального використання природних ресурсів у виробництві - як один зі стандартних елементів більшості визначень «зеленої економіки» ${ }^{17}$.

20-22 червня 2012 р. у Ріо-де-Жанейро відбулася Конференція $\mathrm{OOH}$ зі збалансованого розвитку (Конференція «Ріо+20»), у заключному документі якої «Майбутнє, якого ми прагнемо» підтверджений курс на сталий розвиток і на забезпечення побудови економічно, соціально та екологічно збалансованого майбутнього для планети, для нинішнього і майбутніх поколінь, необхідність подальшого просування ідеї збалансованого розвитку на всіх рівнях та інтеграції його економічної, соціальної та екологічної складових частин і врахування їх взаємозв'язку ${ }^{18}$.

На 70-й сесії Генеральної Асамблеї ООН 25 вересня 2015 р. було прийнято Резолюцію «Перетворення нашого світу: Порядок денний в галузі сталого розвитку на період до 2030 року» (A/RES/70/1), що встановлює 17 цілей і 169 завдань у галузі сталого розвитку, які мають комплексний і неподільний характер та забезпечують збалансованість всіх трьох компонентів сталого розвитку: економічного, соціального та екологічного. У Порядку, зокрема, вказується: «<... нам бачиться світ, в якому кожна країна реалізує можливості для поступального, всеохоплюючого і сталого економічного зростання і гідної роботи для всіх. Світ, в якому моделі споживання та виробництва і використання усіх природних ресурсів <..> мають раціональний характер. Світ, в якому демократія, дієве управління (good governance) і верховенство права (rule of law), а також сприятливі умови на національному та міжнародному рівнях є невід'ємною частиною сталого розвитку,

16 Навстречу «зеленой» экономике: пути к устойчивому развитию и искоренению бедности - обобщающий доклад для представителей властных структур. Доклад ЮНЕП, 2011. URL: www.unep.org/greeneconomy.

17 Цель и темы Конференции Организации Объединенных Наций по устойчивому развитию. Доклад Генерального секретаря, 2011. URL: https://undocs.org/ru/A/CONF.216/PC/7.

18 Будущее, которое мы хотим; Конференция Организации Объединенных наций по устойчивому развитию, Бразилия, Рио-де-Жанейро, 20-22 июня 2012 г. URL: https://rio20.un.org/sites/rio20.un.org/files/a-conf.216-1-1_russian.pdf.pdf. 
включаючи поступальне і всеосяжне економічне зростання, соціальний розвиток, охорону навколишнього середовища та ліквідацію злиднів і голоду $<. .>\gg\left(\right.$ п. 9) ${ }^{19}$.

У результаті «Ріo+20» був започаткований Глобальний звіт зі сталого розвитку (GSDR), в 2016 р. після затвердження вказаної резолюції держави вирішили, що такий звіт має стати обов'язковим і формуватися експертами раз на чотири роки.

Перша така доповідь про глобальний сталий розвиток «Майбутнє вже зараз: наука для досягнення сталого розвитку» підготовлена Незалежною групою вчених, призначеною Генеральним секретарем ООН, і представлена 11 вересня 2019 р.

У звіті зазначається, що нинішня модель розвитку не є сталою і що прогрес, досягнутий за останні два десятиліття, може виявитися зведений нанівець через в т.ч. потенційно незворотне погіршення стану навколишнього середовища, яке забезпечує наше існування, що досягти набагато сприятливішого майбутнього можна тільки за допомогою радикальної зміни політики, стимулів і заходів в області розвитку у процесі розірвання зв'язку між економічним зростанням і погіршенням стану навколишнього середовища за одночасного скорочення соціальної і гендерної нерівності в матеріальному достатку, доходах і доступі до можливостей ${ }^{20}$.

Висновку про взаємозалежність екологічної безпеки та сталого розвитку доходять і в науковій літературі.

Так, щодо розуміння поняття сталого розвитку, як зазначає доктор історичних наук А. Вебер, при всьому різноманітті його визначень, більшість сходиться на тому, що йдеться про такий розвиток, «який не підриває природних і соціальних умов для нормального, здорового життя людей сьогодні і в майбутньому; це довгострокова мета, що передбачає вирішення безлічі економічних, екологічних, соціальних та управлінських завдань у комплексі» ${ }^{21}$.

Екологічну безпеку зазвичай автори трактують або через «сукупність дій, процесів», «діяльність», або через «стан». Причому, як

19 Resolution adopted by the General Assembly on 25 September 2015 [without reference to a Main Committee (A/70/L.1)] 70/1. Transforming our world: the 2030 Agenda for Sustainable Development. URL: https://documents-dds-ny.un.org/doc/UNDOC/GEN/N15/291/89/PDF/ N1529189.pdf?OpenElement.

20 The Future is Now: Science for Achieving Sustainable Development, is the first Global Sustainable Development Report prepared by the Independent Group of Scientists appointed by the United Nations Secretary-General. URL: https://sustainabledevelopment.un.org/gsdr2019.

21 Вебер А. Появится ли у России стратегия устойчивого развития? Обозреватель Observer. 1999. № 10. 
зауважує К.В. Бутова 22 , саме визначення безпеки через певний стан превалює як у міжнародних актах і актах національного права, так і в юридичній та інших науках.

Треба погодитися 3 думкою фахівців ${ }^{23}$, що найширше визначення екологічної безпеки дає в цьому контексті B.I. Андрейцев: «Екологічна безпека як юридична категорія - це складова чапстина національної і транснаціональної безпеки, тобто такий стан розвитку суспільних правовідносин і відповідних їм правових зв'язків, за яких системою правових норм, інших державно-правових і соціальних засобів гарантується захищеність права громадян на безпечне для життя і здоров'я довкілля, забезпечується регулювання здійснення екологічно небезпечної діяльності і запобігання погіршенню стану довкілля та інших наслідків, небезпечних для життя і здоров'я особи, суспільства і держави, яка потребує чіткої конституціоналізації в чинному законодавстві $»^{24}$.

Цікавим із точки зору взаємозв'язку зі сталим розвитком є визначення, надане у 1999 р. М. Хильком: екологічна безпека - «це сукупність певних властивостей навколишнього середовища і створюваних цілеспрямованою діяльністю людини умов, при яких з урахуванням економічних, соціальних факторів і науково обгрунтованих допустимих навантажень на об'єкти біосфери утримується на мінімально можливому рівні ризику антропогенний вплив на навколишнє середовище і негативні зміни, які відбуваються в ньому, забезпечується збереження здоров'я життєдіяльності людей і виключаються віддалені наслідки цього впливу для нинішнього і наступних поколінь» ${ }^{25}$. При цьому пізніше, у 2017 р. в підручнику «Екологічна безпека України» автор вже визначає екологічну безпеку одночасно через «сукупність дій та комплекс відповідних заходів, процесів, які забезпечують екологічний баланс на планеті та в різних ії регіонах на рівні, до якого людина може адаптуватися фізично, без збитків (політичних, соціальноекономічних)», будь-яку «діяльність людини, що виключає згубний вплив на екологічне середовище та не порушує баланс природних або змінених людиною природних компонентів середовища і процесів,

22 Бутова Е.В. Экологическая безопасность в системе национальной безопасности: проблемы современного понимания. Bопросы безопасности. 2016. № 6. С. 98. DOI: 10.7256/2409-7543.2016.6.21573. URL: http://e-notabene.ru/nb/article_21573.html.

23 Бригадир I.В. Щодо визначення екологічної безпеки як правової категорії. Форум права. 2010. № 4. C. 112. URL: http://www.nbuv.gov.ua/e-journals/FP/2010-4/10bivjpk.pdf.

24 Андрейцев В.І. Право екологічної безпеки. Київ : Знання-Прес, 2002. С. 38.

25 Хилько М.І. Екологічна політика. Київ : Абрис, 1999. 
що зумовлює тривале або необмежене в часі існування певної екосистеми» (с. 22), та як «стан сталої і динамічної рівновагі функціонування системи «природа-суспільство», що характеризується, з одного боку, захищеністю природного середовища від руйнівного антропогенного впливу і здатністю до самовідтворення екосистем, з іншого - захищеністю суспільства від екологічних загроз і стихійних лих, забезпеченням здорових природних умов його життєдіяльності» (с. 38$)^{26}$.

Узагальнюючи, можна зробити висновок, що системно-синергетичний характер забезпечення безпеки через перехід до сталого розвитку не виключає суперечностей між основними його складниками, i загальне рішення припускає, що на різних етапах такого переходу на пріоритетне місце буде висуватися яка-небудь одна з них і в кожен момент часу синергетичний чинник використовує стан безпеки для формування наступного безпечного стану. Навіть у межах моделі несталого розвитку необхідним є досягнення певного рівня стабільності й безпеки, для того щоб можна було здійснити перехід до сталого розвитку.

\section{2. Принципи еколого-економічного розвитку та принципи екологічного підприємництва}

Причиною неефективності державної політика сталого розвитку в Україні є домінування індустріального ресурсокористування, яке властиве пострадянським країнам, високий рівень регуляторного та нормотворчого впливу Міністерства енергетики та захисту довкілля України (раніше - Міністерства екології та природних ресурсів України), що не завжди спирається на міжнародні та європейські стандарти, новітні розробки.

Як представляється, для забезпечення роботи формули «екологія-економіка-безпека» як альтернативу традиційним формам господарювання можна розглядати розробку і провадження в Україні концепції екологічного підприємництва.

Розвиток екологічного підприємництва, безпосередньо пов'язаного 3 «зеленою» економікою, потребує державного впливу задля створення належних умов здійснення діяльності в цій сфері. Це можливе через реалізацію ефективної державної політики, яка характеризується, насамперед, наявністю чітко визначеної мети та принципів, що, своєю чергою, є підгрунтям для розробки конкретних способів, засобів та заходів.

26 Хилько М.І. Екологічна безпека України. Київ, 2017. 
Нині в Україні відсутнє комплексне законодавче регулювання екологічного підприємництва, яке $є$ необхідною умовою його запровадження, не зупиняючись на аналізі всієї можливої концепції екологічного підприємництва, зосередимось на формулюванні мети та принципів державної політики у цій сфері через призму реалізації цілей сталого розвитку.

Державна політика у сфері екологічного підприємництва має враховувати ключові положення основних засад (стратегію) державної екологічної політики України на відповідний період. Так, до 1 січня 2020 р. був чинний Закон України «Про Основні засади (стратегію) державної екологічної політики України на період до 2020 року». Відповідно до розділу II цього закону, метою національної екологічної політики була стабілізація і поліпшення стану навколишнього природного середовища України шляхом інтеграції екологічної політики до соціально-економічного розвитку України для гарантування екологічно безпечного природного середовища для життя і здоров'я населення, впровадження екологічно збалансованої системи природокористування та збереження природних екосистем ${ }^{27}$.

Із січня 2020 р. набув чинності новий Закон України «Про Основні засади (стратегію) державної екологічної політики України на період до 2030 року», відповідно до якого метою державної екологічної політики визначено досягнення доброго стану довкілля шляхом запровадження екосистемного підходу до всіх напрямів соціально-економічного розвитку України з метою забезпечення конституційного права кожного громадянина України на чисте та безпечне довкілля, впровадження збалансованого природокористування і збереження та відновлення природних екосистем ${ }^{28}$.

Узагальнюючи норми цих та інших нормативно-правових актів, а також погоджуючись із проведеними раніше дослідженнями ${ }^{29}$, варто зазначити, що метою державної політики у сфері екологічного підприємництва може бути: зміцнення позицій екологічного підприємництва у загальній структурі вітчизняної економіки; створення сприятливих

27 Про Основні засади (стратегію) державної екологічної політики України на період до 2020 року : Закон України від 21 грудня 2010 року № 2818-VI. URL: //http://zakon0.rada.gov. ua/laws/show/2818-17/print.

28 Про Основні засади (стратегію) державної екологічної політики України на період до 2030 року : Закон України від 28 лютого 2019 року № 2697-VIII. URL: https://zakon.rada.gov. ua/laws/show/2697-19.

29 Правове забезпечення розвитку екологічного підприємництва («зеленої» економіки) : Монографія. За заг.ред. А.Г. Бобкової. Вінниця : ТОВ «Ніалан-ЛТД», 2018. С. 110-111. 
умов для екологічного підприємництва; підвищення рівня конкурентоспроможності суб'єктів екологічного підприємництва; стимулювання інвестиційної та інноваційної активності суб'єктів екологічного підприємництва; сприяння провадженню суб'єктами екологічного підприємництва діяльності щодо просування виробленої ними екологічної продукції (товарів, робіт, послуг), насичення вітчизняного ринку високоякісною екологічною продукцією.

Ще однією важливою складовою частиною для визначення змісту державної політики у сфері екологічного підприємництва є принципи державної політики в цій сфері, які є критеріями вибору шляхів досягнення визначеної мети.

Не заглиблюючись у теоретичне визначення принципів, яке існує у філософських та юридичних науках, зосередимо увагу на понятті принципів державного управління. Зазначимо, що нині відсутне однозначне визначення цього поняття. У більшості наукових праць вихідною передумовою дослідження принципів $є$ їх тлумачення як основних засад, керівних ідей, вихідних положень, основних правил поведінки тощо. Так, В.Маліновський зазначає, що принципи державного управління - це фундаментальні істини, позитивні закономірності, керівні ідеї, основні положення, норми поведінки, що відображають закони розвитку відносин управління, сформульовані у вигляді певного наукового положення, закріпленого переважно у правовій формі, на основі якого будується і функціонує апарат державного управління ${ }^{30}$. На думку Г. Атаманчука, принципи державного управління повинні мати джерелами об'єктивні управлінські явища і процеси, розкривати їхню природу та управлінську роль; правильно, на основі точного відображення дійсності, описувати закономірності, відносини та взаємозв'язки державно-управлінської реальності, відображатись у такій формі, яка відповідає вимогам діалектичної логіки, показувати сутність визначеного державно-управлінського відношення, сприяти ефективному використанню наукових знань у практиці ${ }^{31}$. Принципи управління мають відповідати таким вимогам: відображати тільки найбільш суттєві, головні закономірності та взаємозв'язки в державному управлінні; характеризувати лише стійкі закономірності, відносини та взаємозв'язки; охоплювати переважно такі закономірності, відносини, взаємозв'язки, які

\footnotetext{
30 Малиновський В.Я. Державне управління: навчальний посібник. 2-ге вид. Київ : Атіка, 2003. C. 190.

31 Атаманчук Г.В. Теория государственного управления : учебник. Москва : Издательство «ОмегаЛ», 2010. С. 236.
} 
властиві державному управлінню як цілісному соціальному явищу; відображати специфіку державного управління, його відмінність від інших видів управління ${ }^{32}$. Принципи характеризуються двома ознаками належністю до пізнаних наукою і практикою позитивних закономірностей та фіксованістю в суспільній свідомості (у відповідних поняттях) $)^{33}$.

Таким чином, принцип $\epsilon$ центральним поняттям, основоположною ідеєю, яка пронизує систему будь-яких знань. Оскільки нині здебільшого відмовляються від розмежування управління й політики ${ }^{34}$ (до того ж їх зв’язок є безперечним), припустимо, що принципи державної політики у сфері екологічного підприємництва $є$ тотожними принципам державного управління у цій сфері.

3 огляду на вищенаведене, під принципами державної політики у сфері екологічного підприємництва варто розуміти такі основні правила, засади, керівні ідеї, положення, об'єктивні закономірності розвитку екологічного підприємництва та діяльності керівних органів державної влади, які є орієнтирами, вимогами іiі реалізації і відображають найбільш суттєві взаємозв'язки та закономірності, що мають на меті сприяння розвитку цієї сфери ${ }^{35}$.

Запропоноване визначення принципів державної політики у сфері екологічного підприємництва, надбання сучасної науки 3 цього питання, а також останні зміни до законодавства варто врахувати та спробувати сформувати власний перелік принципів державної політики у сфері екологічного підприємництва. Однак перед цим звернемо увагу на зарубіжний досвід деяких країн із питань державної політики та державного регулювання в галузі екологічного підприємництва («зеленої» економіки).

Так, одним із прикладів може бути досвід Республіки Казахстан. У цій республіці є Стратегія «Казахстан-2050» та Концепція з переходу Республіки Казахстан до «зеленої економіки» як економіки з високим рівнем якості життя населення, дбайливим і раціональним

\footnotetext{
32 Атаманчук Г.В. Теория государственного управления. Курс лекций. Москва : Омега-Л, 2004. C. 265.

33 Державне управління : підручник: у 2-х т. Нац. акад. держ. упр. при Президентові України; ред. кол.: Ю.В.Ковбасюк (голова), К.О. Ващенко (заст. голови), Ю.П. Сурмін (заст. голови) та ін.. Київ; Дніпропетровськ : НАДУ, 2012. Т. 1. С. 180.

34 Тертичка В. Державна політика: аналіз та здійснення в Україні. Київ : Видавництво Соломії павличко «Основи», 2002. С. 92.

35 Краковська А.Є. Щодо принципів державної політики у сфері екологічного підприємництва. Екологія Донбасу: уроки історії та виклики сьогодення: матеріали міжнародної науково-практичної конференції, смт. Графське, 10-11 жовтня 2017 р. 2017. C. 91-94.
} 
використанням природних ресурсів в інтересах нинішнього і майбутніх поколінь і відповідно до прийнятих країною міжнародних екологічних зобов'язань. «Зелена економіка» як один із найважливіших інструментів забезпечення сталого розвитку країни дасть змогу Казахстану забезпечити досягнення поставленої мети по входженню в 30 найбільш розвинених країн світу, додатково збільшити ВВП, створити нові робочі місця, сформувати нові галузі промисловості і сфери послуг, забезпечити високі стандарти якості життя для населення.

Концепція переходу Республіки Казахстан до «зеленої економіки» закріпила основні принципи переходу до «зеленої економіки»: підвищення продуктивності ресурсів; відповідальність за використання ресурсів; модернізація економіки з використанням найбільш ефективних технологій забезпечення інвестиційної привабливості заходів щодо ефективного використання ресурсів; реалізація, в першу чергу, рентабельних заходів; навчання та формування екологічної культури в бізнесі і серед населення ${ }^{36}$.

Стосовно ж України, то державна політика в галузі екологічного підприємництва має визначатися відповідно до Конституції Верховною Радою України і бути спрямована на ефективне використання в екологічному підприємництві фінансових, матеріальних та трудових ресурсів, передової технології та техніки, управлінського досвіду, забезпечення стабільності умов екологічного підприємництва. Деякі кроки в цьому напрямі вже зроблені.

Так, нині в Україні діють закони України «Про засади внутрішньої і зовнішньої політики» ${ }^{37}$, «Про Національну безпеку» ${ }^{38}$, «Про Основні засади (стратегію) державної екологічної політики України на період до 2030 року» та «Про засади державної регіональної політики» ${ }^{39}$. Вони базуються на безумовному додержанні Конституції України, забезпеченні в Україні прав і свобод людини і громадянина та гарантуванні прав і свобод, проголошених Конституцією України, на загальновизнаних принципах i нормах міжнародного права,

\footnotetext{
36 Концепция перехода Республики Казахстан к «зеленой экономике» : Указ Президента Республики Казахстан № 577 от 30.05.2013 г. URL: //https://online.zakon.kz/Document/?doc_ id=31399596.

37 Про засади внутрішньої і зовнішньої політики : Закон України № 2411-VI від 01.07.2010 p. URL: https://zakon.rada.gov.ua/laws/show/2411-17.

38 Про Національну безпеку: Закон України від 21.06.2018 p. № 2469-VIII. URL: https://zakon.rada.gov.ua/laws/show/2469-19.

39 Про засади державної регіональної політики : Закон України № 156-VIII від 05.02.2015 p. URL: https://zakon.rada.gov.ua/laws/show/156-19.
} 
забезпеченні соціальної спрямованості економіки України та сталого соціально-економічного розвитку України, зміцненні демократичних засад суспільного і державного життя, забезпеченні верховенства права, економічної і політичної незалежності держави, захисту іiї національних інтересів, утвердження України як повноправного і авторитетного члена світового співтовариства.

Так, відповідно до Закону України «Про засади внутрішньої та зовнішньої політики» внутрішня та зовнішня політика грунтується на відповідних принципах. Однак саме ст. 9 цього Закону закріплює основні засади внутрішньої політики в екологічній сфері та сфері техногенної безпеки, а саме: забезпечення конституційних прав громадян на безпечне довкілля, створення екологічно і техногенно безпечних умов життєдіяльності населення, посилення просвітницької діяльності з інформування населення про екологічні норми і стандарти; збереження навколишнього природного середовища, вдосконалення національної екологічної політики, стимулювання розвитку екобезпечних технологій; забезпечення комплексного захисту населення та реабілітації території від негативного впливу наслідків Чорнобильської катастрофи, подолання наслідків Чорнобильської катастрофи; здійснення заходів щодо безпечного поводження з радіоактивними відходами, зняття з експлуатації Чорнобильської АЕС та перетворення об'єкта «Укриття» на екологічно безпечну систему; підвищення рівня цивільного захисту населення і територій від надзвичайних ситуацій техногенного та природного характеру; впровадження системи екологічно збалансованого використання природних ресурсів.

Відповідно до ч. 1 ст. 3 Закону України «Про Національну безпеку» державна політика у сферах національної безпеки і оборони спрямована на захист, в т.ч. умов для сталого розвитку суспільства, навколишнього природного середовища від надзвичайних ситуацій. Ч. 2 цієї статті містить основні принципи, що визначають порядок формування державної політики у сферах національної безпеки і оборони, зокрема, участь України у міжнародних зусиллях із підтримання миру і безпеки, міждержавних системах та механізмах міжнародної колективної безпеки. Крім того, державна політика у сферах національної безпеки й оборони спрямовується не тільки на забезпечення воєнної, зовнішньополітичної, державної, економічної, інформаційної, а й екологічної безпеки (ч. 4 ст. 3 Закону).

Закон України «Про Основні засади (стратегію) державної екологічної політики України на період до 2030 року» закріпив основні 
засади державної екологічної політики, зазначивши, що реалізація цих засад здійснюється за принципами: відкритості, підзвітності, гласності органів державної влади; участі громадськості у формуванні державної політики; дотримання екологічних прав громадян; запобігання екологічній шкоді; міжнародної співпраці та євроінтеграції; заохочення до ведення екологічно відповідального бізнесу та екологічно свідомої поведінки громадян. У процесі виділення основних інструментів реалізації державної політики також виокремлені міжнародне співробітництво у сфері охорони навколишнього природного середовища та забезпечення екологічної безпеки, економічні та фінансові механізми, зокрема екологічна модернізація, стабільне фінансування природоохоронної діяльності та стимулювання розвитку екологічного підприємництва; створення суб' єктами господарювання систем екологічного управління (розділ II Закону).

Закон України «Про засади державної регіональної політики» визначає основні правові, економічні, соціальні, екологічні, гуманітарні та організаційні засади державної регіональної політики як складової частини внутрішньої політики України. Відповідно до ст. 4 цього Закону державна регіональна політика реалізується на принципах, серед яких принцип сталого розвитку суспільства для задоволення потреб нинішнього покоління з урахуванням інтересів майбутніх поколінь.

Враховуючи вищезазначене і те, що Україна проголошує екологічне підприємництво однією з пріоритетних галузей економіки, створює умови для його розвитку, а також ті основоположні засади (принципи), які закріплені в законах України «Про засади внутрішньої і зовнішньої політики», «Про Національну безпеку», «Про Основні засади (стратегію) державної екологічної політики України на період до 2030 року» та «Про засади державної регіональної політики» та інших законодавчих актах, пов'язаних із сферою підприємництва та/або екологією, варто закріпити на рівні закону такі основні принципи державної політики у сфері екологічного підприємництва:

1) забезпечення сталого соціально-економічного розвитку;

2) пріоритетність розвитку та державної підтримки екологічного підприємництва у процесі формування та реалізації державної економічної політики, розроблення відповідних нормативно-правових актів;

3) забезпечення участі представників суб'єктів екологічного підприємництва, громадських організацій, що представляють інтереси суб'єктів екологічного підприємництва, у формуванні та реалізації державної політики в зазначеній сфері; 
4) ефективність використання бюджетних коштів, передбачених для виконання програм розвитку екологічного підприємництва;

5) ефективність та доступність отримання державної підтримки суб'єктами екологічного підприємництва, суб'єктами господарювання, що здійснюють модернізацію виробництва, спрямовану на зменшення негативного впливу на навколишнє природне середовище;

6) створення рівних можливостей для доступу суб'єктів екологічного підприємництва, що відповідають вимогам, передбаченим загальнодержавними, регіональними та місцевими програмами екологічного підприємництва, до участі у виконанні зазначених програм та для отримання державної підтримки;

7) відкритість і прозорість проведення процедур надання державної підтримки та стимулювання вітчизняних суб'єктів екологічного підприємництва, які здійснюють модернізацію виробництва, спрямовану на зменшення негативного впливу на навколишне природнє середовище;

8) забезпечення взаємодії науки, освіти, виробництва, фінансовокредитної сфери в розвитку екологічного підприємництва;

9) впровадження навчальних та освітніх ініціатив із цільового навчання, підвищення кваліфікації та перепідготовки кадрів для екологічного підприємництва;

10)розвиток соціального діалогу у процесі формування та реалізації державної політики в екологічному підприємництві з питань регулювання економічних, трудових і соціальних відносин;

11)розвиток міжнародного науково-технічного співробітництва, використання міжнародної кооперації у виробництві та обігу екологічної продукції.

\section{ВИСНОВКИ}

Узагальнюючи наведене вище, можна дійти наведених нижче висновків.

Перехід до сталого розвитку можливий лише в глобальному масштабі, у злагоджено когерентному режимі всіх об'єктів і суб'єктів безпеки.

Забезпечення загальної безпеки безпосередньо пов'язане з переходом до сталого розвитку, відповідно, поняття безпеки грунтується на концепції сталого розвитку.

3 одного боку, безпека як благо в сталому розвитку набуває комплексного характеру певної гарантованої комфортності людського 
існування, а $з$ другого - виступає змістовним виміром сталого розвитку. В онтологічному аспекті це означає, що безпека загалом і екологічна безпека зокрема - певна доцільна відстань між людством і природою, яка забезпечує їх цивілізаційний діалог.

Системно-синергетичний характер забезпечення безпеки через перехід до сталого розвитку не виключає суперечностей між основними його складниками, і загальне рішення припускає, що на різних етапах такого переходу на пріоритетне місце буде висуватися яка-небудь одна з них і в кожен момент часу синергетичний чинник використовує стан безпеки для формування наступного безпечного стану. Навіть у межах моделі несталого розвитку необхідним є досягнення певного рівня стабільності й безпеки, щоб можна було здійснити перехід до сталого розвитку.

\section{АНОТАЦІЯ}

Глобалізація екологічних проблем, сукупна ентропія, що має тенденцію до збільшення, посилення еколого-економічного взаємозв'язку, що базується на єдності природної та господарської підсистем макроекономічної системи будь-якого ієрархічного рівня, зумовлюють необхідність пошуку нових моделей економіки, які б враховували відтворювальні можливості біосфери.

У статті на підставі аналізу сформованих у доктрині підходів до розуміння сталого розвитку, екологічної безпеки, положень міжнародних актів охарактеризовані особливості еколого-економічного виміру безпеки, обгрунтовано взаємозв'язок і взаємозалежність екологічної безпеки та сталого еколого-економічного розвитку.

Зокрема, доведено, що перехід до сталого розвитку можливий лише в глобальному масштабі, в злагоджено когерентному режимі всіх об'єктів і суб'єктів безпеки. Обгрунтовано, що, з одного боку, безпека як благо в сталому розвитку набуває комплексного характеру певної гарантованої комфортності людського існування, а з другого - виступає змістовним виміром сталого розвитку. В онтологічному аспекті це означає, що безпека загалом і екологічна безпека зокрема - певна доцільна відстань між людством і природою, яка забезпечує їх цивілізаційний діалог. Визначено, що системно-синергетичний характер забезпечення безпеки через перехід до сталого розвитку не виключає суперечностей між основними його складниками, і загальне рішення припускає, що на різних етапах такого переходу на пріоритетне місце буде висуватися яка-небудь одна 3 них і в кожен момент часу синер- 
гетичний чинник використовує стан безпеки для формування наступного безпечного стану.

Крім того, пропонується авторська редакція мети та принципів державної політики у сфері екологічного підприємництва, провадження концепції якого пропонується в Україні з метою забезпечення роботи формули «екологія-економіка-безпека».

\section{ЛIТЕРАТУРА}

1. Conférence Internationale pour de la Natur, Berne, 17-19 November 1913, Recueil des Procés-Verbaux. P. 25-26.

2. Fitzmaurice M.A. The contribution of environmental law to the development of modern environmental law / J. Makarczyk (ed.). Theory of International Law at the threshold of the 21st century: Essays in honour of Krzysztof Skubiszewski. The Hague: Kluwer Law International, 1966. $921 \mathrm{p}$.

3. Resolution adopted by the General Assembly on 16 September 2005 [without reference to a Main Committee (A/60/L.1)] 60/1. 2005 World Summit Outcome. URL: https://documents-dds-ny.un.org/doc/UNDOC/GEN/ N05/487/62/PDF/N0548762.pdf?OpenElement.

4. Resolution adopted by the General Assembly on 25 September 2015 [without reference to a Main Committee (A/70/L.1)] 70/1. Transforming our world: the 2030 Agenda for Sustainable Development. URL: https://documents-dds-ny.un.org/doc/UNDOC/GEN/N15/291/89/PDF/ N1529189.pdf?OpenElement.

5. The Future is Now: Science for Achieving Sustainable Development, is the first Global Sustainable Development Report prepared by the Independent Group of Scientists appointed by the United Nations Secretary-General. URL: https://sustainabledevelopment.un.org/gsdr2019.

6. Андрейцев В.І. Право екологічної безпеки. Київ : Знання-Прес, 2002. $332 \mathrm{c}$.

7. Атаманчук Г.В. Теория государственного управления : учебник. Москва : Издательство «ОмегаЛ», 2010. 525 с.

8. Бригадир І.В. Щодо визначення екологічної безпеки як правової категорії. Форум права. 2010. № 4. C. 109-114. URL: http://www.nbuv.gov. ua/e-journals/FP/2010-4/10bivjpk.pdf.

9. Будущее, которое мы хотим; Конференция Организации Объединенных наций по устойчивому развитию, Бразилия, Рио-деЖанейро, 20-22 июня 2012 г. URL: https://rio20.un.org/sites/rio20.un.org/ files/a-conf.216-1-1_russian.pdf.pdf.

10. Бутова Е.В. Экологическая безопасность в системе национальной безопасности: проблемысовременногопонимания. Вопросы безопасности. 
2016. № 6. C. 90-100. DOI: 10.7256/2409-7543.2016.6.21573. URL: http://e-notabene.ru/nb/article_21573.html.

11. Василенко В. Генеза, зміст і шляхи реалізації концепції міжнародної екологічної безпеки. Екологічна Конституція Землі. Методологічні засади. Львів, РВВ НЛТУ України, 2011. С. 54-63.

12. Вебер А. Появится ли у России стратегия устойчивого развития? Обозреватель-Observer. 1999. № 10.

13. Гринів Л.С. Екологічна економіка. Львів : Магнолія, 2006, 2010. $358 \mathrm{c}$.

14. Державне управління : підручник: у 2-х т. Нац. акад. держ. упр. при Президентові України; ред. кол.: Ю.В. Ковбасюк (голова), К.О. Ващенко (заст. голови), Ю.П. Сурмін (заст. голови) та ін. Київ; Дніпропетровськ : НАДУ, 2012. Т. 1.564 с.

15. ЗадорожнійО.В., Медведєва М.О. Міжнароднеправо навколишнього середовища : підручник. Київ, 2010. 355 с.

16. Іванова Т. Державне управління сталим екологічним розвитком України та ї̈ регіонів в системі раціонального природокористування: теорія, методологія, перспективні напрями. Монографія. Київ : ВПЦ АМУ, 2011. 405 c.

17. Колдунова Е.В. Формирование регионального комплекса безопасности в Восточной Азии в свете новых угроз и нетрадиционных аспектов безопасности : автореф. дис. ... канд. полит. наук : 23.00.04 «Политические проблемы международных отношений и глобального развития». Москва, 2009. 22 c. URL: http://cheloveknauka.com/formirovanie-regionalnogokompleksa-bezopasnosti-v-vostochnoy-azii-v-svete-novyh-ugroz-inetraditsionnyh-aspektov-bezopas\#ixzz4Ld7JBaQE.

18. Концепция по переходу Республики Казахстан к «зеленой экономике» : Указ Президента Республики Казахстан № 577 от 30.05.2013 г. URL: https://online.zakon.kz/Document/?doc_id=31399596.

19. Краковська А.С. Щодо принципів державної політики у сфері екологічного підприємництва. Екологія Донбасу: уроки історії та виклики сьогодення : матеріали міжнародної науково-практичної конференції, смт. Графське, 10-11 жовтня 2017 р., 2017. С. 91-94.

20. Кулагин В. Глобальная или мировая безопасность. Международные процессы. Журнал теории международных отношений и мировой политики. 2007. Том 5. № 2(14). Май-август. URL: www.intertrends.ru.

21. Ліпкан В. Поняття та зміст націобезпекознавства. Право Украӥни. 2003. № 9. С. 114-118.

22. Малиновський В.Я. Державне управління : навчальний посібник. 2-ге вид. Київ : Атіка, 2003. 576 с. 
23. Международная Хартия Земли (Международный Совет инициативы Хартия Земли; Международный Секретариат Хартии Земли. Сан-Хосе (Коста-Рика)). URL: http://www.newlineclub.net/downloads/eci/winter\%20 school/materials/earth\%20charter/Mezhdunarodny_sovet_ECI.pdf.

24. Навстречу «зеленой» экономике: пути к устойчивому развитию и искоренению бедности - обобщающий доклад для представителей властных структур. Доклад ЮНЕП, 2011. URL: www.unep.org/ greeneconomy.

25. Олдак П.Г. Общие начала биосоциальных исследований. Теория взаимосвязи общественного производства и окружающей сферы. Москва : Изд-во НГУ, 1977. 71 с.

26.Правове забезпечення розвитку екологічного підприємництва («зеленої» економіки) : монографія / За заг. ред. А.Г. Бобкової. Вінниця : ТОВ «Ніалан-ЛТД», 2018. 230 с.

27. Про засади внутрішньої і зовнішньої політики : Закон України № 2411-VI від 01.07 .2010 p. URL: https://zakon.rada.gov.ua/laws/ show/2411-17.

28. Про засади державної регіональної політики: Закон України № 156-VIII від 05.02 .2015 p. URL: https://zakon.rada.gov.ua/laws/ show/156-19.

29. Про Національну безпеку: Закон України № 2469-VIII від 21.06.2018 p. URL: https://zakon.rada.gov.ua/laws/show/2469-19.

30. Про Основні засади (стратегію) державної екологічної політики України на період до 2020 р. : Закон України № 2818-VI від 21 грудня 2010 p. URL: http://zakon0.rada.gov.ua/laws/show/2818-17/print.

31. Про Основні засади (стратегію) державної екологічної політики України на період до 2030 р. : Закон України № 2697-VIII від 28.02.2019 р. URL: https://zakon.rada.gov.ua/laws/show/2697-19.

32. Ситник Г. Інституційно-цивілізаційна парадигма дослідження проблем та державно-управлінських аспектів забезпечення національної безпеки. Вісник Національної академії державного управління при Президентові Украӥни. 2011. Вип. 2. С. 25-34. URL: http://nbuv.gov.ua/ UJRN/Vnadu_2011_2_6.

33. Тертичка В. Державна політика: аналіз та здійснення в Україні. Київ : Видавництво Соломії Павличко «Основи», 2002. 750 с.

34.Урсул А.Д. Проблемы безопасности и устойчивого развития: эволюционный подход и междисциплинарные перспективы. Bonpocbl безопасности. 2014. № 5. C. 1-62. URL: http://e-notabene.ru/nb/ article_14221.html.

35. Фатхутдинов В. Щодо системного синтезу безпекових концепцій. Підприємниитво, господарство і право. 2012. № 12. С. 108-110. 
36. Хилько М. Екологічна політика. Київ : Абрис, 1999. 364 с.

37. Хилько М.І. Екологічна безпека України. Київ, 2017. 267 с.

38. Цель и темы Конференции Организации Объединенных Наций по устойчивому развитию. Доклад Генерального секретаря, 2011. URL: https://undocs.org/ru/A/CONF.216/PC/7.

\section{Information about authors:}

Turchenko O. H.,

Ph.D., Associate Professor,

Head of the Constitutional, International and Criminal Law Department

Vasyl' Stus Donetsk National University

21, st. 600-richchia, Vinnytsia, Ukraine

Krakovska A. Ye.,

Ph.D., Associate Professor,

Head of Theory and History of State and Law and Administrative Law

Department

Vasyl' Stus Donetsk National University

21, st. 600-richchia, Vinnytsia, Ukraine

DOI https://doi.org/10.30525/978-9934-588-43-3/2.24 